\title{
In Vivo Antitumor Activity of Metal Silver and Silver Nanoparticles in the L5178Y-R Murine Lymphoma Model
}

\author{
José H. Lara-González ${ }^{1}$, Ricardo Gomez-Flores ${ }^{1 *}$, \\ Patricia Tamez-Guerra ${ }^{1}$, Enriqueta Monreal-Cuevas ${ }^{1}$, \\ Reyes Tamez-Guerra ${ }^{1}$ and Cristina Rodríguez-Padilla ${ }^{1}$
}

${ }^{1}$ Departamento de Microbiología e Inmunología, Universidad Autónoma de Nuevo León, Facultad de Ciencias Biológicas, San Nicolás de los Garza, NL. México.

Authors' contributions

This work was carried out in collaboration between all authors. Author RGF designed the study, was the thesis advisor of author JHLG and wrote the final version of the manuscript. Author JHLG performed the experiments and statistical analysis for his Master of Sciences thesis and wrote the first draft of the manuscript. Author PTG managed the analysis of the study. Author EMC supported the study as a technician and data managing. Authors RTG and CRP managed the analysis of the study. All authors read and approved the final manuscript.

Research Article

Received $22^{\text {nd }}$ January 2013 Accepted $23^{\text {rd }}$ March 2013 Published $12^{\text {th }}$ April 2013

\section{ABSTRACT}

Aims: To evaluate the antitumor potential of metal silver and polyvinilpyrrolidone nanoparticle-encapsulated silver on L5178Y-R murine lymphoma cell growth and survival of tumor-bearing mice.

Study Design: In vitro and in vivo (pre-clinical) study.

Place and Duration of Study: Universidad Autónoma de Nuevo León, Facultad de Ciencias Biológicas, Departamento de Microbiología e Inmunología, San Nicolás de los Garza, N.L., México, from January 2009 to December 2011.

Methodology: Concentration-response cell viability assay was performed in vitro and mice survival studies were done using a L5178Y-R tumor-bearing mouse model. The $\mathrm{PROBIT}$ regression analysis was performed to determine the in vitro $\mathrm{LC}_{50}$. In vivo survival distributions were calculated by Kaplan-Meier and Cutler-Ederer analysis, and 
survival curves comparisons and hypothesis testing was done using the log-rank method.

Results: Metal silver induced up to $100 \%$ L5178Y-R cells cytotoxicity, with an LC $_{50}$ of $1.8 \times 10^{-8} \mathrm{M}$, whereas silver nanoparticles caused up to $78 \%$ cytotoxicity, with an LC $_{50}$ of $14.4 \times 10^{-8} \mathrm{M}$. In addition, Intramuscular administration of metal silver and silver nanoparticles administered at the time of tumor injection significantly $(P=.05)$ increased mice survival, where $70 \%$ and $60 \%$ of mice survived at day 35 respectively, as compared with such treatments administered 7 days after tumor induction $(55 \%$ and $25 \%$ survival respectively); vincristine treatment caused $50 \%$ mice survival and tumor-bearing control mice had $20 \%$ survival. These results open further approaches on treating several types of cancer using free and nanoparticle-encapsulated silver-based therapies.

Keywords: Silver; silver nanoparticles; lymphoma; antitumor activity; preclinical; mouse.

\section{INTRODUCTION}

Cancer is one of the major death causes. In 2008, it was responsible for 7.6 millions of deaths worldwide, particularly in the economically developing countries, and it continuously increases because of the aging and growth of the world population and cancer-causing behaviors [1]. The T-cell acute lymphoblastic leukemia(T-ALL) presents several drawbacks related to currently used therapies, for example, increased risk to septicemias and fungal infections [2], the unlikelihood of reaching disease-free remission [3], the high risk of severe and continuous neutropenias after subsequent rounds of chemotherapy [4], and the inability to sometimes achieve a successful stem-cell transplantation along with the question whether all patients with proper blood-related donor should receive an allogenic transplant or whether this should be reserved only for high-risk patients [5]. All together, it is essential to search for new chemotherapeutic approaches to treat T-ALL, as well as other types of cancer. Silver colloids and silver nanoparticles have previously demonstrated bactericidal, bacteriostatic [6] and antiviral activity [7]. In addition, in vitro evaluations have confirmed cytotoxic activity against some tumor cell lines [7]. However, no investigations have been conducted to demonstrate their effectiveness to increase tumor-bearing mice survival. The aim of the present study was to evaluate the antitumoral activity of polyvinylpyrrolidone (PVP)-coated silver nanoparticles and metal silver against the murine lymphoma cell line L5178Y-R in vitro, as well as to evaluate their effectiveness in a tumor-bearing mouse model. It was observed that Metal silver and silver nanoparticles induced up to $100 \%$ and $78 \%$ L5178Y-R cells in vitro cytotoxicity, respectively; in addition, in vivo treatment of tumor-bearing mice with metal silver and silver nanoparticles administered at the time of tumor injection significantly increased mice survival, as compared with controls.

\section{MATERIALS AND METHODS}

\subsection{Reagents and Culture Medium}

L-glutamine and penicillin-streptomycin solutions were obtained from Life Technologies (Grand Island, NY). RPMI 1640 medium, fetal bovine serum (FBS), sodium dodecyl sulfate (SDS), N, N-dimethylformamide (DMF), phosphate-buffered saline (PBS), and 3-[4,5dimethylthiazol-2-yl]-2,5-diphenyltetrazolium bromide (MTT) were purchased from SigmaAldrich (St. Louis, MO). Vincristine was obtained from Vintec (Columbia, S.A. de C.V., Mexico, DF). The extraction buffer was prepared by dissolving $20 \%(\mathrm{wt} / \mathrm{vol}) \mathrm{SDS}$ at $37^{\circ} \mathrm{C}$ in 
a solution of $50 \%$ each DMF and demineralized water, and the $\mathrm{pH}$ was adjusted to 4.7. Silver nanoparticles were purchased from Nanostructured \& Amorphous Materials, Inc. (Houston, TX). These were spherical $0.2 \mathrm{wt} \%$ polyvinylpyrrolidone-face coated, 30-50 nm average particle size nanoparticles, containing silver powder $(99.9 \% \mathrm{Ag})$, with a specific surface area of $5-10 \mathrm{~m}^{2} / \mathrm{g}$ and cubic cystallographic structure, according to supplier (Nanostructured \& Amorphous Materials, Inc.); 65-75\% Ag purity and $10.49 \mathrm{~g} / \mathrm{cm}^{3}$ (lit.) density colloidal silver was obtained from Sigma-Aldrich (catalog \# 85131). Silver powder and pvp-silver nanoparticles were dissolved or suspended, respectively, at desired concentrations, in complete RPMI 1640 medium for in vitro cytotoxicity assays, or in saline solution for intramuscular administration.

\subsection{Animals}

Six-week old female BALB/c mice (22-28g) were purchased from Harlan Sprague-Dawley Inc. (Indianapolis, IN). They were kept in a pathogen- and stress-free environment at $24^{\circ} \mathrm{C}$, under a light-dark cycle (light phase, 06:00-18:00 h), and given water and food ad libitum.

\subsection{Tumor Cell Line}

The tumor cell line L5178Y-R (mouse DBA/2 lymphoma) was purchased from The American Type Culture Collection. (Rockville, MD), and was maintained in culture flasks with RPMI 1640 medium supplemented with 10\% FBS, $1 \%$ L-glutamine, and $0.5 \%$ penicillinstreptomycin solution (referred as complete RPMI 1640 medium) at $37^{\circ} \mathrm{C}$, in a humidified atmosphere of $5 \% \mathrm{CO}_{2}$ in air. Cellular density was kept between $10^{5}$ and $10^{6}$ cells $/ \mathrm{ml}$.

\subsection{Cell Preparation and Culture}

In order to determine the direct in vitro effect of metal silver and silver nanoparticles on L5178Y-R tumor cell, lymphoma cell cultures were collected and the cellular suspensions were washed three times in RPMI 1640, and re-suspended and adjusted to $5 \times 10^{4}$ cells $/ \mathrm{ml}$ with complete RPMI medium.

\subsection{Effect of Metal Silver or Silver Nanoparticles on L5178Y-R Lymphoma Cell Cytotoxicity}

One hundred microliters of L5178Y-R cell suspensions were added to flat-bottomed 96-well plates (Becton Dickinson, Cockeysville, MD), containing triplicate cultures (100 $\mu \mathrm{l})$ of complete RPMI (unstimulated control), metal silver or silver nanoparticles at various concentrations. After incubation for $44 \mathrm{~h}$ at $37^{\circ} \mathrm{C}$ with $5 \% \mathrm{CO}_{2}$, MTT $(0.5 \mathrm{mg} / \mathrm{ml}$, final concentration) was added, and cultures were additionally incubated for $4 \mathrm{~h}$. Next, cell cultures were incubated for $16 \mathrm{~h}$ with extraction buffer $(100 \mu \mathrm{l})$ and optical densities, resulting from dissolved formazan crystals, were then read in a microplate reader (DTX 880 Multimode detector, Becton Dickinson, Austria) at $570 \mathrm{~nm}$ [8]. The percentage of lymphoma cytotoxicity was calculated as follows:

$$
\% \text { cytotoxicity }=100-\frac{A_{570} \text { in metal silver- or silver nanoparticles-treated cells }}{A_{570} \text { in untreated cells }} \times 100
$$


Considering $65-75 \%$ Ag purity in metal silver solution and $99.9 \%$ Ag purity in nanoparticles suspension, treatments were performed at equimolar concentrations and results expressed in \% cytotoxicity at concentrations ranging from 0.9 to $57.9 \times 10^{-8} \mathrm{M}$. For this, $116 \times 10^{-8} \mathrm{M}$ stock silver solutions (metal) and suspensions (nanoparticles) were prepared by using $357 \mu \mathrm{g} / \mathrm{ml}$ and $250 \mu \mathrm{g} / \mathrm{ml}$, respectively, and 1:2 serial dilutions were made to provide for the assay treatment concentrations.

\subsection{In vivo Tumor-bearing Mice Survival by Metal Silver and Silver Nanoparticles}

We used the L5178Y-R lymphoma mouse model to test metal silver and silver nanoparticles antitumor activity. The lymphoma was maintained and administered to Balb/c mice as previously reported [8]. Every experiment consisted of 9 groups of 5 mice; L5178Y-R cells $\left(5 \times 10^{6}\right.$ cells $\left./ \mathrm{mL}\right)$ suspended in $0.2 \mathrm{~mL}$ of PBS were intramuscularly (i.m.) injected in the right thigh on 6 groups. Treatment groups consisted of i.m. administration of metal silver or silver nanoparticles $(20 \mathrm{mg} / \mathrm{kg}$ ) at day 0 (at the time of tumor injection), i.m. administration of metal silver or silver nanoparticles $(20 \mathrm{mg} / \mathrm{kg})$ at day 7 of tumor injection; other groups were untreated tumor-bearing mice, i.m. vincristine $(0.55 \mathrm{mg} / \mathrm{kg})$ treated tumor-bearing mice (every third day; positive control), i.m. administration of metal silver or silver nanoparticles (20 mg/kg) alone (toxicity control) and untreated mice (negative control). Treatments were applied every second day (except for vincristine) to complete 30 days. Overall survival was registered during the 35 day-study.

\subsection{Statistical Analysis}

The results were expressed as mean \pm SEM of the response of 3 replicate determinations per treatment (in vitro study) or 5 mice per experimental group ( 9 groups as explained above) from three independent experiments. Level of significance was assessed by Dunnet's $t$ test; to calculate the $\mathrm{LC}_{50}$ in vitro, a PROBIT regression model was used. Survival curves were calculated by the Kaplan-Meier and the Cutler-Ederer methods, and the statistical significance of differences in the survival curves between the groups was evaluated by log-rank test.

\section{RESULTS AND DISCUSSION}

\subsection{In vitro Cytotoxicity Tests}

Metal silver induced from $44 \%$ to $100 \%$ significant $(P<.01)$ L5178Y-R cells cytotoxicity, at testing molar concentrations ranging from 0.9 to $57.9 \times 10^{-8} \mathrm{M}$ respectively, with an $\mathrm{LC}_{50}$ of $1.8 \times 10^{-8} \mathrm{M}$, whereas silver nanoparticles caused from $11 \%$ to $78 \%$ significant $(P \leq .05)$ cytotoxicity at the same concentration range respectively, with an $L_{50}$ of $14.4 \times 10^{-8} \mathrm{M}$ (Fig. 1). Metal silver cytotoxic effect was significantly $(P<0.01)$ higher than that of silver nanoparticles. Metal silver was not toxic for normal murine thymic lymphocytes at concentrations as high as $28.9 \times 10^{-8} \mathrm{M}$, but was observed to stimulate Con A-treated lymphoproliferation, whereas silver nanoparticles induced thymus lymphocyte proliferation up to $7.2 \times 10^{-8} \mathrm{M}$, but caused toxicity from $14.4 \times 10^{-8} \mathrm{M}$ (data not shown). It is known that pvp-coated silver nanoparticles are targeted to several body tissues, in particular, towards tumor cells $[9,10]$. 


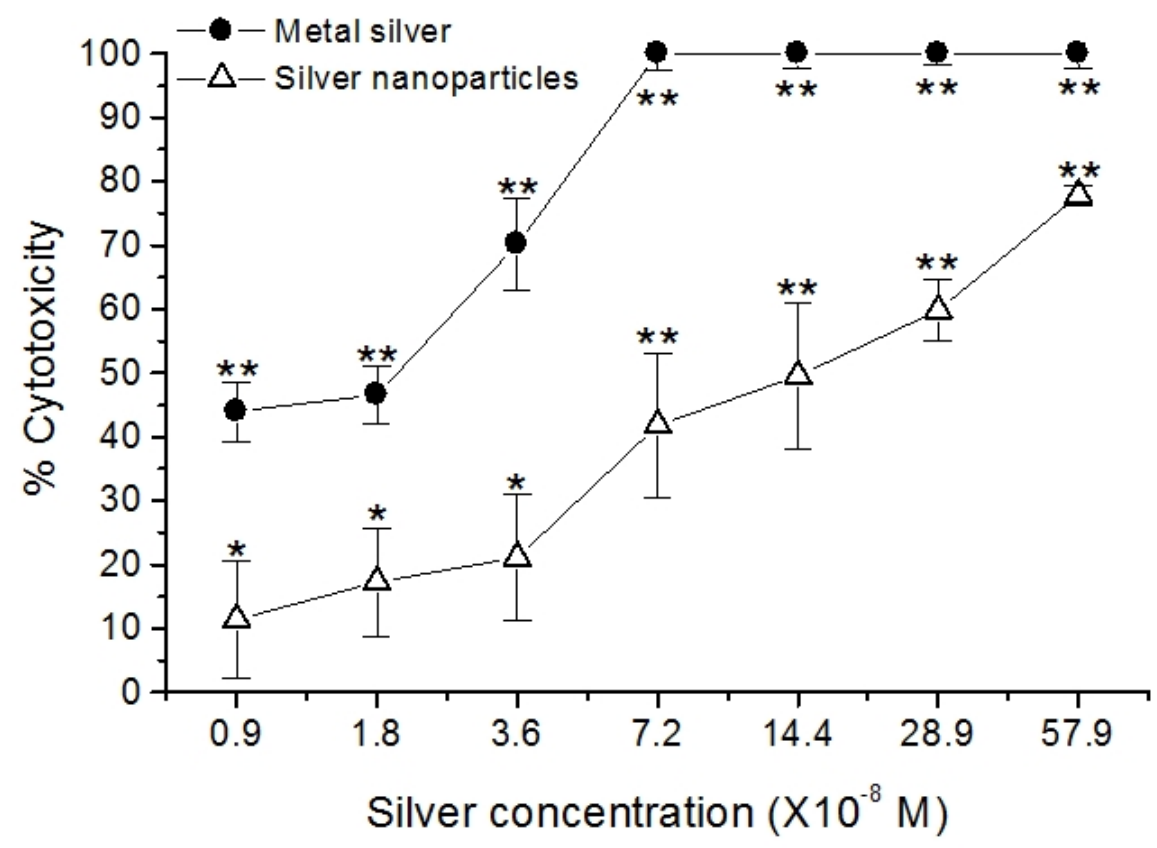

Fig. 1. Cytotoxicity induced by metal silver and silver nanoparticles on L5178Y lymphoma cells. L5178Y-R lymphoma cells $\left(5 \times 10^{4}\right.$ cells $\left./ \mathrm{ml}\right)$ were incubated in the presence or absence of metal silver and silver nanoparticles at concentrations ranging from 0.9 to $57.9 \times 10^{-8} \mathrm{M}$ for $44 \mathrm{~h}$, after which viability was measured using MTT, as explained in the text. Optical densities were read in a microplate reader at $\mathbf{5 7 0}$ $\mathrm{nm}$. Optical density for untreated control was $0.65 \pm 0.09$. Data represent mean \pm standard error of triplicates from three independent experiments. ${ }^{*} P<0.05$; ${ }^{* *} P<.01$, as compared with untreated control

The cytotoxic activity of silver particulate nano-compounds has been investigated on animal cell lines being the inhibitory concentration $20\left(\mathrm{IC}_{20}\right) 16.7 \times 10^{-6} \mathrm{M}$ for L5178Y-R cells $[10,11]$; it was furthermore demonstrated that nano-compounds can induce primary DNA damage in animal cell cultures, notwithstanding being incapable to induce mutagenicity [10]. In our study, we showed that metal or silver nanoparticles caused necrosis, rather than apoptosis, on L5178Y-R cells (data not shown) and the highest concentration tested was $57.9 \times 10^{-8} \mathrm{M}$ (Fig. 1), which may indicate a more potent activity as compared with other reports [10], or it may be due that we did not filter the silver treatments prior to use, which other authors commonly do [10], because we observed significant silver retention on the filter.

It has been reported that silver nanoparticle delivery to mammal cells by the nano-carrier chitosan induces apoptosis at very low concentrations (on HT-29 human colon cancer cells), the $\mathrm{LC}_{50}$ was determined as $0.3 \times 10^{-8} \mathrm{M}$, and it was proposed that this concentration was more effective than previously reported data [12]. However, our results indicated LC $_{50}$ of 1.8 $X 10^{-8} \mathrm{M}$ and $14.4 \times 10^{-8} \mathrm{M}$ by metal silver and pvp-coated silver nanoparticles respectively, as compared with that of chitosan-carried nanoparticles, showing differential activities of silver nanoparticles depending on their composition and on the tumor cell type, but both preparations were significantly toxic for tumor cells. It has also been indicated that the biological activity of silver nanoparticles is mediated mainly by silver which are present at the 
initial phase of dispersion or that they are eventually released by the nanoparticles throughout time [13]. In the present study, we observed that metal silver caused 8-fold lower LC50 than silver nanoparticles, which may be due to the availability of the silver to tumor cells, which may be reduced after encapsulation. We also observed that both treatments caused necrosis on L5178Y-R lymphoma cells (data not shown), which agrees with a report related to the use of 7 - to $20-\mathrm{nm}$ silver nanoparticles $\left(12 \times 10^{-8} \mathrm{M}\right)$ inducing cell death by necrosis on HT-1080 human fibrosarcoma cells and A431 skin carcinoma cells, and apoptosis at about $0.9 \times 10^{-8} \mathrm{M}[14]$.

The cytotoxic response and the type of cell death induced by silver nanoparticles on several cell lines and several types of in vitro tissues has been previously investigated; reported data have shown that the nanoparticle size may play a role on inducing toxicity, being $15-\mathrm{nm}$ particles more toxic than $30 \mathrm{~nm}$ and $55 \mathrm{~nm}$-nanoparticles, as reported for macrophages, where nanoparticles caused apoptosis [15]. It was also demonstrated that the type of cell death induced on A549 lung cancer cells by silver nanoparticles relies mainly on a dosedependent fashion (2.3-14 $\left.\times 10^{-8} \mathrm{M}\right)$, that induces necrosis/late apoptosis in most cells, whereas increasing the dose induces early apoptosis in a small proportion of A540 cells [16]. We have further confirmed the phenomenon of necrosis observed in our study, by not detecting caspase family proteases after in vitro cell death induction (data not shown).

\subsection{Effect of Metal Silver and Silver Nanoparticles on In vivo Tumor-bearing Mice Survival}

Intramuscular administration of metal silver and silver nanoparticles administered at day 0 (at the time of tumor injection) significantly $(P=.05)$ increased the survival of mice, as compared with such treatments or vincristine applied 7 days post tumor injection and untreated control (with tumor). In regard with metal silver and silver nanoparticles administered at day $0,70 \%$ and $60 \%$ of mice survived at day 35 respectively, as compared with such treatments applied 7 days post tumor injection where $55 \%$ and $25 \%$ of mice survived respectively. Vincristine treatment caused $50 \%$ mice survival and tumor-bearing control mice had $20 \%$ survival after 35 days (Table 1 ); metal silver and silver nanoparticle treatments alone, and untreated control (without tumor) did not affect mice survival (Table 1).

Table 1. Effect of metal silver and silver nanoparticles on L5178Y-R tumor-bearing mice survival (\%)

\begin{tabular}{llllllll}
\hline Treatment & Days & & & & & \\
\cline { 2 - 8 } & $\mathbf{5}$ & $\mathbf{1 0}$ & $\mathbf{1 5}$ & $\mathbf{2 0}$ & $\mathbf{2 5}$ & $\mathbf{3 0}$ & $\mathbf{3 5}$ \\
\hline Vincristine & 100 & 100 & 100 & 100 & 80 & 53 & 47 \\
Untreated tumor-bearing & 100 & 100 & 100 & 100 & 80 & 50 & 20 \\
Metal silver (7 days post-tumor) & 100 & 100 & 100 & 66 & 58 & 51 & 51 \\
$\begin{array}{l}\text { Metal silver (at tumor injection day) } \\
\text { Silver nanoparticles (7 days post- }\end{array}$ & 93 & 93 & 93 & 93 & 93 & 73 & 66 \\
$\begin{array}{l}\text { tumor) } \\
\text { Silver nanoparticles (at tumor }\end{array}$ & 100 & 100 & 100 & 80 & 60 & 40 & 26 \\
injection day) & 93 & 86 & 86 & 86 & 80 & 66 & 51 \\
Metal silver alone & & & & & & & \\
Nanoparticles alone & 100 & 100 & 100 & 100 & 100 & 100 & 100 \\
Tumorless non-treated control & 100 & 100 & 100 & 100 & 100 & 100 & 100 \\
\hline & 100 & 100 & 100 & 100 & 100 & 100 & 100 \\
\hline
\end{tabular}

In vivo studies are scarce, but they have shown antitumor or angiogenic potential in a variety of tumor types, different from our murine L5178Y-R lymphoma model. One of such studies 
reported that aqueous dispersions of silver oxide nanoparticles, inhibited tumor growth in vivo on a Pliss lymphosarcoma rat model [17]. In addition, Liu et al. [18] demonstrated that a nanopharmaceutical system using TAT-enhanced cell/tissue penetration strategy, developed for multidrug-resistant cancer treatment, possessed strong antitumor activity, particularly using a melanoma murine model. In contrast, Kang et al. [19] showed that PVP-coated silver nanoparticles (average size 2.3nm) caused in vivo angiogenesis in B16F10 melanomas in mice.

Previous reports have demonstrated that heparin-conjugated silver nanoparticles possess angiogenesis inhibitory properties which are mediated by the basic fibroblast growth factor [20], and it was also demonstrated that silver nanoparticles of $50 \mathrm{~nm}$ in diameter can act as a potent antiangiogenic factor in two in vivo models (rat and mouse models), and that this effect induced by the vascular endothelial growth factor is mediated by inhibition of the cell survival signal PI3K/Akt, in a similar fashion as that mediated by the pigment epitheliumderived factor in bovine retinal endothelial cells [21]. However, another study suggested that exposure to pvp-coated silver nanoparticles of $2.3 \mathrm{~nm}$ in size can induce angiogenesis in an in vivo model and on the SVEC4-10 cell line in vitro [19]. In our study, we used pvp-coated silver nanoparticles of a diameter of $30-50 \mathrm{~nm}$, being similar to those used by Gurunathan et al. [21], in addition to metal silver solution. Both treatments, particularly the ones administered at tumor injection day, significantly increased the survival distributions, in comparison with the non-treated control in a murine lymphoma model, which may be mediated by their potential antiangiogenic effect, in combination with the direct cytotoxic response observed in vitro (Fig. 1 and Table 1) [21].

Using this study as a base, we also demonstrated for the first time that polyvinylpyrrolidonecoated silver nanoparticles and silver ions effectively increase the survival distributions in a tumor-bearing mouse model in vivo.

\section{CONCLUSION}

Pvp-coated silver nanoparticles and silver ions showed in vitro cytotoxicity on the L5178Y-R lymphoma cell line. In addition, we have shown the effectiveness of two silver colloid-based therapies to significantly increase the survival response on a solid tumor-bearing mouse model, particularly, when administered at day of tumor injection, which might be useful for treating solid tumors on initial stages of development, or during therapy to prevent relapses. We also demonstrated that the treatments induced a better survival response in comparison with vincristine administered on day 7 post tumor induction, which is a chemotherapeutic drug commonly used to treat acute leukemia.

\section{CONSENT}

Not applicable.

\section{ETHICAL APPROVAL}

All authors hereby declare that "Principles of laboratory animal care" (NIH publication no. 8523 , revised 1985) were followed, as well as specific national laws. All experiments have been examined and approved by the Institutional Ethics Committee. 


\section{COMPETING INTERESTS}

Authors have declared that no competing interests exist.

\section{REFERENCES}

1. Ahmedin J, Bray F, Center MM, Ferlay J, Ward E, Forman D. Global cancer statistics. CA: Cancer J Clinicians. 2011;61(2):69-90.

2. Hurwitz CA, Silverman LB, Schorin MA. Substituting dexamethasone for prednisone complicates remission induction in children with acute lymphoblastic leukemia. Cancer. 2000;88:1964-9.

3. Annino L, Vegna ML, Camera A. Treatment of adult acute lymphoblastic leukemia (ALL): long-term follow-up of the GIMEMA ALL 0288 randomized study. Blood. 2002;99:863-71.

4. Gökbuget N, Hoelzer D. The role of high-dose cytarabine in induction therapy for adult ALL. Leuk Res. 2002;26:473-6.

5. Hoelzer D, Gökbuget N, Ottmann O, Pui CH, Relling MV, Appelbaum FR. Acute lymphoblastic leukemia. Hematology (Am Soc Hematol Educ Program). 1992;162192.

6. Kim JS, Kuk E. Antimicrobial effects of silver nanoparticles. Nanomedicine. 2007;3(1):95-101.

7. Lara HH, Ayala-Nuñez NV, Ixtepan-Turrent L, Rodriguez-Padilla C. Mode of antiviral action of silver nanoparticles against HIV-1. J Nanobiotechnol. 2010;8:1.

8. Gomez-Flores R, Caballero-Hernández D, Tamez-Guerra R, Rodríguez-Padilla C, Tamez-Guerra P, Rice KC, Hicks ME, Weber RJ. Increased survival of tumor-bearing mice by the delta opioid SNC 80. Anticancer Res. 2005;25(6C):4563-67.

9. Ghosh P. Hydrophilic polymeric nanoparticles as drug Carriers. Indian J Biochem Biophys. 2000;37:273-82.

10. Youn-Jung K, Sungi Ik Y, Jae-Chu R. Cytotoxicity and genotoxicity of nano-silver in mammalian cell lines. Mol Cell Toxicol. 2010;6:119-25.

11. Asharani PV, Hande MP, Valiyaveettil S. Anti-proliferative activity of silver nanoparticles. BMC Cell Biol. 2009;10:65.

12. Sanpui P, Chattopadhyay A, Ghosh SS. Induction of apoptosis in cancer cells at low silver nanoparticle concentrations using chitosan nanocarrier. ACS Appl. Mater. Interfaces. 2011;3(2):218-28.

13. Koch M, Kiefer S, Cavelius C, Kraegeloh A. Use of a silver ion selective electrode to assess mechanisms responsible for biological effects of silver nanoparticles. J Nanoparticle Res. 2011;14:646.

14. Arora S, Jain J, Rajwade JM, Paknikar KM. Cellular responses induced by silver nanoparticles: In vitro studies. Toxicol Lett. 2008;179:93-100.

15. Carlson C, Hussain SM, Schrand AM, Braydich-Stolle LK, Hess KL, Jones RL et al. Unique cellular interaction of silver nanoparticles: size-dependent generation of reactive oxygen species. J Phys Chem B. 2008;112(43):13608-19.

16. Foldbjerg R, Dang, DA, Autrup H. Cytotoxicity and genotoxicity of silver nanoparticles in the human lung cancer cell line, A549. Arch Toxicol. 2010;3:279-290.

17. Rutberg FG, Dubina MV, Kolikov VA, Moiseenko FV, Ignat'eva EV, Volkov NM et al. Effect of silver oxide nanoparticles on tumor growth in vivo. Dokl Biochem Biophys. 2008;421:191-3.

18. Liu J, Zhao Y, Guo Q, Wang Z, Wang H, Yang Y, et al. TAT-modified nanosilver for combating multidrug-resistant cancer. Biomaterials. 2012;33(26):6155-61. 
19. Kang K, Lim DH, Choi IH, Kang T, Lee K, Moon EY, et al. Vascular tube formation and angiogenesis induced by polyvinylpyrrolidone-coated silver nanoparticles. Toxicol Lett. 2011;205(3):227-34.

20. Kemp MM, Kumar A, Mousa S, Dyskin E, Yalcin M, Ajayan P et al. Gold and silver nanoparticles conjugated with heparin derivative possess anti-angiogenesis properties. Nanotechnology. 2009;11;20(45):455104.

21. Gurunathan S, Lee KJ, Kalishwaralal K, Sheikpranbabu S, Vaidyanathan R, Eom SH. Antiangiogenic properties of silver nanoparticles. Biomaterials. 2009;30(31):6341-50.

(c) 2013 Lara-González et al.; This is an Open Access article distributed under the terms of the Creative Commons Attribution License (http://creativecommons.org/licenses/by/3.0), which permits unrestricted use, distribution, and reproduction in any medium, provided the original work is properly cited.

\section{Peer-review history:}

The peer review history for this paper can be accessed here:

http://www.sciencedomain.org/review-history.php?iid=205\&id=12\&aid=1242 